\title{
Evaluation of Local Isolates of Trichoderma Spp. against Black Root Rot (Fusarium solani) on Faba Bean
}

\author{
Eshetu Belete $^{1 *}$, Amare Ayalew ${ }^{2}$ and Seid Ahmed ${ }^{3}$
}

${ }^{1}$ Department of Plant Sciences, P.O. Box 1145, Wollo University, Dessie, Ethiopia

${ }^{2}$ School of Plant Sciences, P.O. Box 241, Haramaya University, Ethiopia

${ }^{3}$ International Center for Agricultural Research in the Dry Areas, P O Box 5689, Addis Ababa, Ethiopia

\begin{abstract}
Faba bean (Vicia fabae L.) is one of the most important pulse crops in Ethiopia and is now cultivated on large areas in many countries. In most growing areas, however, the production of the crop is constrained by several disease infections, including fungal diseases. Black root rot caused by Fusarium solani is the most destructive disease of faba bean. The antagonistic potentials of locally isolated Trichoderma spp. from rhizosphere soils of faba bean plants in the highlands of northeastern Ethiopia were evaluated against $F$. solani, responsible for black root rot. All isolates of Trichoderma spp. had strong biological control activity against $F$. solani in vitro as well as in vivo pot experiment. Under dual culture, the percentage of mycelial growth inhibition of $F$. solani by the Trichoderma ranged from 33.9 to $67.0 \%$. The highest $(67.0 \%)$ inhibition was obtained from isolate TS036, while the lowest $(33.9 \%)$ by isolate TS015. Pathogen-inoculated faba bean plants grown in pots that were treated with antagonists had taller plant heights and biomass than the Trichoderma untreated control inoculated with $F$. solani. The Trichoderma isolates significantly reduced black root rot severity on faba bean seedlings with disease reduction ranging from 64.4 to $74.6 \%$ over control. Use of Trichoderma species can be a potential source of biological control agents for the management of black root rot in faba beans grown in the region. Hence, the potential Trichoderma isolates under field condition might used as a components in the integrated management of $F$. solani that caused faba bean black root rot in the highlands of northeastern Ethiopia.
\end{abstract}

Keywords: Antagonist; Biocontrol; Fusarium solani; Inhibition; Rhizosphere; Trichoderma

\section{Introduction}

Faba bean (Vicia fabae L.) is one of the most important pulse crops in the world and is used as a source of protein in human diet for substitute of animal protein, animal feed, generate incomes and improve soil fertility [1]. In Ethiopia, black root rot of faba bean caused by Fusarium solani is the most widespread and destructive disease in black clay soils, where water-logging is severe [2,3] with yield reduction of up to $45 \%$ [4]. A number of management options have been used in minimizing the effects. These include use of resistant varieties; application of cultural practices, such as crop rotation and furrow planting to drain out excess water $[2,5,6]$.

Biological control of plant diseases is considered as one of the viable alternative methods to manage plant diseases $[7,8]$. Application of fungicides is not economical in the long term because they pollute the environment, leave harmful residues and can lead to the development of resistant strains of the pathogen with repeated use [9]. However, use of biological control is safe, nonhazardous for human, farm animals and avoids environmental pollution [7,10]. The application of biological controls using antagonistic microorganisms has proved to be successful for controlling various plant diseases in many countries [11]. Most of these studies were on the control of root and soil-borne plant pathogens and, to a lesser extent of foliar pathogens [12].

One of the most important biological control agents is the use of Trichoderma spp. that are most frequently isolated soil fungi and present in plant root ecosystems $[12,13]$. They colonize the root and rhizosphere of plant and suppress plant pathogens by different mechanisms, such as competition, mycoparasitism, antibiosis production and induced systemic resistance, improvement of the plant health by promote plant growth, and stimulation of root growth [13-17].
The antagonistic activity of the genus Trichoderma to F. solani has been widely demonstrated [18]. Application of T. harzianum as seed treatment significantly reduced the incidence of damping-off diseases of faba bean, lentil, and chickpea, when planted in a soil naturally contaminated with Fusarium spp. and $R$. solani [19]. Trichoderma harzianum, T. koningii and T. viride are reported to improve seedling emergence and health of runner bean (Phseous coccineus) when applied as seed treatments [20,21]. Trichoderma harzianum introduced to the rhizosphere of faba bean plants significantly reduced root rot incidence more than the fungicide Rizolex-T [22].

Little work has been done on Trichoderma spp. as antagonists in the control of faba bean black root rot in Ethiopia. So far, not much previous research has been done on the use of biological control agents for the control of black root rot of faba beans in Ethiopia. The strain of Trichoderma viride, tested in the laboratory, proved to be an effective antagonistic activity against Fusarium solani, black root rot of faba bean $[23,24]$. Therefore, the objective of the present study was to identify native Trichoderma species and to evaluate their antagonistic effects against Fusarium solani on faba bean.

*Corresponding author: Eshetu Belete, Department of Plant Sciences P.O. Box 1145, Wollo University, Dessie, Ethiopia, Tel: 033-3115211; E-mail: ebelete70@gmail.com

Received March 07, 2015; Accepted June 15, 2015; Published June 23, 2015

Citation: Belete E, Ayalew A, Ahmed S (2015) Evaluation of Local Isolates of Trichoderma Spp. against Black Root Rot (Fusarium solani) on Faba Bean. J Plant Pathol Microb 6: 279. doi:10.4172/2157-7471.1000279

Copyright: $\odot 2015$ Belete E, et al. This is an open-access article distributed under the terms of the Creative Commons Attribution License, which permits unrestricted use, distribution, and reproduction in any medium, provided the original author and source are credited. 


\section{Materials and Methods}

\section{Isolation of Trichoderma spp.}

Soil samples were collected from different healthy faba bean growing fields in the highlands of northeastern Ethiopia (Table 1). One hundred gram rhizosphere soil was collected into each sterile plastic bag and kept in the refrigerator at the Plant Pathology Laboratory, Haramaya University, for further analysis. Isolation of antagonistic Trichoderma spp. from rhizosphere soil was made using serial dilution technique [25]. Each composite soil sample was thoroughly mixed and pulverized by means of mortar and pestle, and passed through a 0.5 $\mathrm{mm}$ soil screen sieve before $1 \mathrm{~g}$ was suspended in $9 \mathrm{ml}$ sterile distilled water. The suspensions were made homogeneous by agitation using a vortex mixer and further serial dilutions of $10^{-2}, 10^{-3}$ and $10^{-4}$.

One milliliter of serially diluted suspension from each dilution was pipetted into potato dextrose agar (PDA) medium and the petri plates were thoroughly mixed by gently swirling in clockwise and anti-clockwise direction to uniformly spread the suspension. Isolates of Trichoderma colonies were picked for antagonism studies after incubating the plates at $25 \pm 1^{\circ} \mathrm{C}$ for $48 \mathrm{~h}$. and re-streaked on a new plate but of the same media to obtain pure colonies. Nineteen Trichoderma isolates were identified according to Kubicek and Harman, [26] based on their conidial morphology, color and texture, and growth characteristics and the isolates were confirmed to be Trichoderma koningii ( 17 isolates) and Trichoderma viride ( 2 isolates) (Table 1).

\section{In vitro screening test}

The antagonistic effects of each Trichoderma sp. against $F$. solani were tested using dual culture technique $[10,27]$. The tested isolates of Trichoderma spp. were grown on potato dextrose agar (PDA) medium at $20^{\circ} \mathrm{C}$, for 6-days and used as inocula. Disks from each isolate of Trichoderma spp. (5 $\mathrm{mm}$ in diameter) were inoculated on PDA medium in one side in Petri plate and the opposite side was inoculated by $F$. solani inocula. The inoculated plate with $F$. solani only but without Trichoderma treatment was used as control. The treatments were replicated three times and arranged in a completely randomized design (CRD) and the experiment was repeated. Four and five days after incubation periods at $25 \pm 2^{\circ} \mathrm{C}$, data on growth inhibition zone and colony diameter were recorded for each plate. The radii of the fungal colony towards and away from the antagonistic colony were measured and the percentage growth inhibition was calculated [28] as follows:

$$
\% \text { Inhibition }=\frac{(\mathrm{R}-\mathrm{r})}{\mathrm{R}} \times 100
$$

where, $R$ is the maximum radius of the fungal colony away from the antagonist colony, and $r$ is the radius of the fungal colony opposite the antagonist colony

\section{Greenhouse test}

On the bases of in-vitro results, nine Trichoderma isolates were tested to assess their effects on black root rot development on faba bean seedlings. Trichoderma isolates were grown on the plates and the spores were washed from the plates with sterile distilled water and the concentration was adjusted to $10^{6}$ conidia $\mathrm{ml}^{-1}$. Sterilized faba bean seeds of the susceptible faba bean variety CS-20DK were dipped into the suspension of each Trichoderma spp. for five hrs. Seeds inoculated with sterile water only (i.e. without antagonists) were used as control. The inoculated seeds ( 5 seeds per $15 \mathrm{~cm}$ diameter pot) were planted in sterile black soil (clay 70\%: silt 16\%: sand $14 \%$ ) and kept in the greenhouse at $24-28^{\circ} \mathrm{C}$ during day and $15-20^{\circ} \mathrm{C}$ at night. After a week, each pot was artificially drenched with aggressive isolate of $F$. solani at a rate of $10^{6}$ conidia $\mathrm{ml}^{-1}$. The experiment was conducted in a randomized complete block design (RCBD) with three replications and the experiment was repeated.

One month after planting, plants were removed from the soil and the roots were washed with sterile distilled water and the root rot severity was scored by assessing necrotic lesions on the roots and hypocotyls using a rating scale of $0-4$, where $0=$ hypocotyls and roots white and firm, no root pruning; 1=slightly brown or discolored hypocotyls and roots, slight root pruning; $2=$ moderately discolored hypocotyls and roots, extensive root pruning; $3=$ darkly discolored hypocotyls and roots, hypocotyls completely collapse or, severe root pruning; $4=$ dead or dying plant [29] (McFadden et al.), Based on the disease severity data, percentage of root rot suppression was calculated [30] as follows:

$\%$ Suppression $=\frac{\mathrm{A}-\mathrm{B}}{\mathrm{A}} \times 100$

where, $A$ is the disease severity exhibited in the root region due to $F$. solani alone and $B$ is the disease severity exhibited in the root region after inoculation with both the pathogen and bacterial antagonists. Data of plant height and biomass was also recorded.

\section{Data analyses}

Statistical analyses were performed using General Linear Modeling (GLM) procedure of SAS System for Windows Version 9.1 software [31]. Severity ratings were normalized before analysis using square root transformation with the formula $(X+0.5)^{1 / 2}$, where $X$ is the severity rating of root rot and 0.5 is constant number added [32]. The least significant difference (LSD) test at $5 \%$ level of significance was used to separate treatment means for each measured parameter.

\section{Results}

\section{In vitro screening test}

Isolates of Trichoderma species was found to occur on faba bean rhizospher soil in the three districts of northeastern highlands of Ethiopia (Table 2 and Apendix C3); however, the distribution of isolates was found to vary among the districts. Highest number of isolates was obtained from Jamma, followed by Woreillu and Delanta. The elevation of the sampled areas varied between 2551 and 3017 meters above sea level.

The efficacy of local Trichoderma isolates in inhibiting the mycelial growth of $F$. solani in dual culture was determined on PDA medium. Results of dual culture tests clearly showed that all the isolated

\begin{tabular}{|c|c|}
\hline Isolates & Trichoderma species \\
\hline $\begin{array}{c}\text { TS004, TS007, TS015, TS018, TS019, TS022, } \\
\text { TS025A, TS027, TS030, TS032, TS037, TS041A, } \\
\text { TS047, TS050, TS058, TS064, TS090 }\end{array}$ & Trichoderma koningii \\
\hline TS010, TS036 & Trichoderma viride \\
\hline
\end{tabular}

Table 1: Identification of the local Trichoderma isolates.

\begin{tabular}{|c|c|c|c|}
\hline Districts & Altitude & Grid reference & $\begin{array}{c}\text { Potential antagonistic Tricoderma } \\
\text { isolates }\end{array}$ \\
\hline Delanta & 2885 & $50^{\circ} \mathrm{E}, 12^{\circ} \mathrm{N}$ & TS090 \\
\hline Jamma & $2551-2621$ & $52-53^{\circ} \mathrm{E}, 11^{\circ} \mathrm{N}$ & $\begin{array}{l}\text { TS004, TS007, TS010, TS015, TS018, } \\
\text { TS019, TS022, TS025A, TS027, TS030, } \\
\text { TS032, TS036, TS037, TS041A, }\end{array}$ \\
\hline Woreillu & $2627-2725$ & $54^{\circ} \mathrm{E}, 11^{\circ} \mathrm{N}$ & TS047, TS050, TS058, TS064, \\
\hline
\end{tabular}

Table 2: Occurrence of Trichoderma isolates on the soil rhizospher of faba bean plants in the highlands of northeastern Ethiopia. 
Citation: Belete E, Ayalew A, Ahmed S (2015) Evaluation of Local Isolates of Trichoderma Spp. against Black Root Rot (Fusarium solani) on Faba Bean. J Plant Pathol Microb 6: 279. doi:10.4172/2157-7471.1000279

Trichoderma spp. significantly $(P \leq 0.05)$ inhibited the radial growth of F. solani at varying degrees (Table 3 and Figure 1). These Trichoderma isolates were able to inhibit the mycelial growth of $F$. solani by the range of 33.9 to $67 \%$. Nine isolates significantly inhibited the colony mycelial growth of $F$. solani the most promising isolates resulting in more than $50 \%$ inhibition. Maximum inhibition zone $(67.0 \%)$ was exhibited by the isolate TS036, followed by TS025A (65.9\%) and TS050 (63\%), while the lowest (33.9\%) inhibition was due to the isolate TS015. Generally, the antagonists inhibited the mycelial growth of $F$. solani but could not overgrow the pathogen until three to four days. However, five days later, the Trichoderma overgrew the pathogen and wholly occupied the medium.

\section{Greenhouse test}

The application of antagonists reduced significantly $(P \leq 0.05)$ the extent of black root rot infection in comparison to $F$. solani alone (without Trichoderma isolates) inoculated plants (Table 4). The effectiveness of the antagonists ranged from 69 to $74 \%$ disease suppression over the control. The maximum (74\%) control or suppression of black root rot was observed in bean plants treated with isolate TS025 and TS050, while the lowest $(64.4 \%)$ was with isolate TS058.

In the present study, all antagonists significantly enhanced the height and biomass of bean seedlings as compared to bean seedlings inoculated with F. solani alone (Table 4 and Figure 2). The maximum plant height was observed in plants treated with isolates TS036 (38.5 $\mathrm{cm})$, TS019 $(38.4 \mathrm{~cm})$ and TS007 $(37.9 \mathrm{~cm})$ followed by isolates TS010 $(36.8 \mathrm{~cm})$, TS050 $(36.7 \mathrm{~cm})$, TS058 $(36.6 \mathrm{~cm})$ and TS022 $(34.5 \mathrm{~cm})$, while the shortest $(33.4 \mathrm{~cm})$ plant height was observed in plants treated with isolate TS025. Trichoderma treated seedlings increased in fresh biomass ranging from 24.1 to $40.5 \%$ over the control. Among the potential biological control agents in this study, isolates TS019, TS036, and TS010 resulted in 40.5, 37.8 and 37.4\%, respectively, increased

\begin{tabular}{|c|c|c|c|}
\hline Isolates & $\begin{array}{c}\text { Trichoderma } \\
\text { radius } \mathbf{( m m})\end{array}$ & $\begin{array}{c}\text { Inhibition } \\
\mathbf{( m m})\end{array}$ & Inhibition $(\%)$ \\
\hline TS004 & $49.7 \pm 0.1 \mathrm{~b}-\mathrm{d}$ & $19.3 \pm 0.1 \mathrm{a}$ & $40.2 \pm 0.1 \mathrm{f}$ \\
\hline TS007 & $52.3 \pm 0.2 \mathrm{ab}$ & $13.3 \pm 0.1 \mathrm{c}$ & $55.1 \pm 0.2 \mathrm{~d}$ \\
\hline TS010 & $54.0 \pm 0.1 \mathrm{a}$ & $12.7 \pm 0.2 \mathrm{~cd}$ & $60.5 \pm 5.1 \mathrm{~b}-\mathrm{d}$ \\
\hline TS015 & $50.3 \pm 0.2 \mathrm{bc}$ & $20.7 \pm 0.1 \mathrm{a}$ & $33.9 \pm 2.7 \mathrm{~g}$ \\
\hline TS018 & $50.0 \pm 0.2 \mathrm{~b}-\mathrm{d}$ & $16.7 \pm 0.2 \mathrm{~b}$ & $47.4 \pm 5.0 \mathrm{e}$ \\
\hline TS019 & $52.3 \pm 0.2 \mathrm{ab}$ & $11.3 \pm 0.2 \mathrm{~d}-\mathrm{f}$ & $61.4 \pm 4.4 \mathrm{a}-\mathrm{c}$ \\
\hline TS022 & $50.0 \pm 0.1 \mathrm{~b}-\mathrm{d}$ & $12.3 \pm 0.2 \mathrm{c}-\mathrm{e}$ & $60.7 \pm 3.8 \mathrm{~b}-\mathrm{d}$ \\
\hline TS025A & $51.7 \pm 0.2 \mathrm{ab}$ & $10.7 \pm 0.1 \mathrm{ef}$ & $65.9 \pm 1.2 \mathrm{ab}$ \\
\hline TS027 & $47.0 \pm 0.2 \mathrm{de}$ & $19.3 \pm 0.1 \mathrm{a}$ & $34.8 \pm 1.7 \mathrm{fg}$ \\
\hline TS030 & $45.7 \pm 0.5 \mathrm{e}$ & $19.3 \pm 0.2 \mathrm{a}$ & $37.0 \pm 2.8 \mathrm{fg}$ \\
\hline TS032 & $47.0 \pm 0.3 \mathrm{de}$ & $20.0 \pm 0.0 \mathrm{a}$ & $34.8 \pm 1.3 \mathrm{fg}$ \\
\hline TS036 & $49.6 \pm 0.1 \mathrm{~b}-\mathrm{d}$ & $10.3 \pm 0.1 \mathrm{f}$ & $67.0 \pm 1.6 \mathrm{a}$ \\
\hline TS037 & $49.7 \pm 0.1 \mathrm{~b}-\mathrm{c}$ & $16.0 \pm 0.1 \mathrm{~b}$ & $47.2 \pm 3.5 \mathrm{e}$ \\
\hline TS041A & $48.0 \pm 0.3 \mathrm{c}-\mathrm{e}$ & $17.0 \pm 0.2 \mathrm{~b}$ & $40.1 \pm 5.9 \mathrm{f}$ \\
\hline TS047 & $51.3 \pm 0.2 \mathrm{ab}$ & $12.0 \pm 0.1 \mathrm{c}-\mathrm{f}$ & $60.4 \pm 3.2 \mathrm{~b}-\mathrm{d}$ \\
\hline TS050 & $49.3 \pm 0.2 \mathrm{c}-\mathrm{d}$ & $11.3 \pm 0.1 \mathrm{~d}-\mathrm{f}$ & $63.0 \pm 0.5 \mathrm{a}-\mathrm{c}$ \\
\hline TS058 & $49.3 \pm 0.1 \mathrm{~b}-\mathrm{d}$ & $12.3 \pm 0.1 \mathrm{c}-\mathrm{e}$ & $58.6 \pm 5.8 \mathrm{~cd}$ \\
\hline TS064 & $49.7 \pm 0.1 \mathrm{~b}-\mathrm{d}$ & $19.6 \pm 0.1 \mathrm{a}$ & $34.3 \pm 2.0 \mathrm{fg}$ \\
\hline TS090 & $49.3 \pm 0.1 \mathrm{~b}-\mathrm{d}$ & $20.0 \pm 0.0 \mathrm{a}$ & $35.9 \pm 5.1 \mathrm{fg}$ \\
\hline Control & - & 31.6 & - \\
\hline CV\% & 3.89 & 7.05 & 7.11 \\
\hline
\end{tabular}

Values in parentheses are square root transformed $(x+0.5)^{1 / 2}$ values.

Means within column followed by the same letter(s) are not significantly different from each other at $5 \%$ level of significance.

Table 3: Effects of Trichoderma isolates on the radial growth (inhibition) of Fusarium solani.
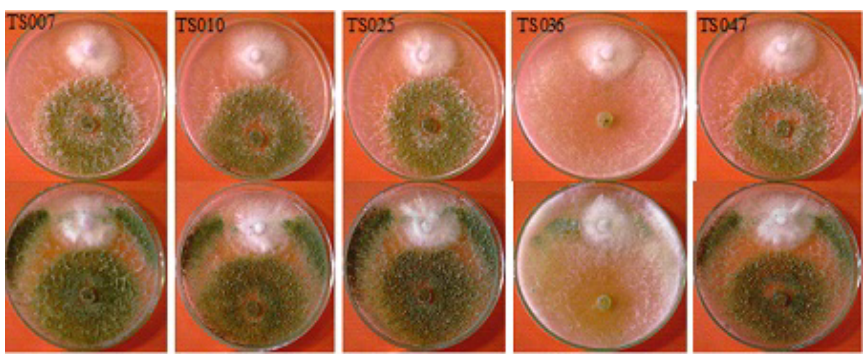

Figure 1: Differences In vitro antagonistic effect of selected Trichoderma isolates against Fusarium solani using dual culture method four (top) and five (bottom) days after inoculation. At the bottom of the plates overwhelming growth of Trichoderma isolate on $F$. solani, which indicates parasitic interaction. Heavy sporulation by Trichoderma is seen on and in vicinity of $F$. solani colony. Each perti dish has F. solani at the upper and Trichoderma at the lower side of the petri plate.

\begin{tabular}{|c|c|c|c|c|c|}
\hline \multirow[b]{2}{*}{$\begin{array}{c}\text { Isolate } \\
\text { code }\end{array}$} & \multirow{2}{*}{$\begin{array}{l}\text { Disease } \\
\text { severity } \\
\text { (0-4 scale) }\end{array}$} & \multirow{2}{*}{$\begin{array}{c}\text { Disease } \\
\text { suppression } \\
(\%)\end{array}$} & \multirow{2}{*}{$\begin{array}{c}\text { Plant } \\
\text { height } \\
(\mathrm{cm})\end{array}$} & \multicolumn{2}{|c|}{ Plant biomass } \\
\hline & & & & $\begin{array}{c}\text { Fresh weight } \\
\text { (g) }\end{array}$ & $\begin{array}{c}\text { Dry } \\
\text { weight (g) }\end{array}$ \\
\hline TS007 & $1.20(1.30) b$ & 69.5 & $37.9 \pm 3.2 \mathrm{a}$ & $46.8 \pm 7.4 a-c$ & $6.8 \pm 1.6 b$ \\
\hline TS010 & $1.07(1.23) b$ & 72.8 & $36.8 \pm 4.5 a b$ & $51.4 \pm 3.7 a b$ & $7.7 \pm 0.5 a b$ \\
\hline TS019 & $1.07(1.23) b$ & 72.8 & $38.4 \pm 0.9 a$ & $54.1 \pm 2.7 a$ & $8.5 \pm 0.2 a$ \\
\hline TS022 & $1.06(1.23) b$ & 73.0 & $34.5 \pm 1.6 a b$ & $47.1 \pm 3.3 a-c$ & $7.0 \pm 0.5 b$ \\
\hline TS025 & $1.00(1.20) b$ & 74.6 & $33.4 \pm 2.4 b$ & $48.3 \pm 3.7 a-c$ & $7.2 \pm 0.5 b$ \\
\hline TS036 & $1.07(1.23) b$ & 72.8 & $38.5 \pm 2.1 \mathrm{a}$ & $51.8 \pm 7.3 \mathrm{ab}$ & $7.2 \pm 0.8 b$ \\
\hline TS047 & $1.13(1.27) b$ & 71.3 & $33.5 \pm 2.4 b$ & $42.4 \pm 2.1 \mathrm{c}$ & $6.9 \pm 0.3 b$ \\
\hline TS050 & $1.00(1.20) b$ & 74.6 & $36.7 \pm 1.6 a b$ & $49.5 \pm 3.1 \mathrm{a}-\mathrm{c}$ & $7.3 \pm 0.5 b$ \\
\hline TS058 & $1.40(1.37) b$ & 64.4 & $36.6 \pm 1.5 a b$ & $45.5 \pm 3.6 b c$ & $6.7 \pm 0.4 b$ \\
\hline Control & $3.93(2.10) a$ & 0.0 & $28.8 \pm 1.9 c$ & $32.2 \pm 2.9 d$ & $4.8 \pm 0.6 c$ \\
\hline Mean & 1.39 & & 35.5 & 46.9 & 7.0 \\
\hline CV\% & 8.84 & & 6.76 & 9.48 & 8.92 \\
\hline
\end{tabular}

Values in parentheses are square root transformed $(x+0.5)^{1 / 2}$ values.

Means within column followed by the same letter(s) are not significantly different from each other at $5 \%$ level of significance.

Table 4: Efficacies of potential Trichoderma isolates on faba bean black root rot under greenhouse condition.
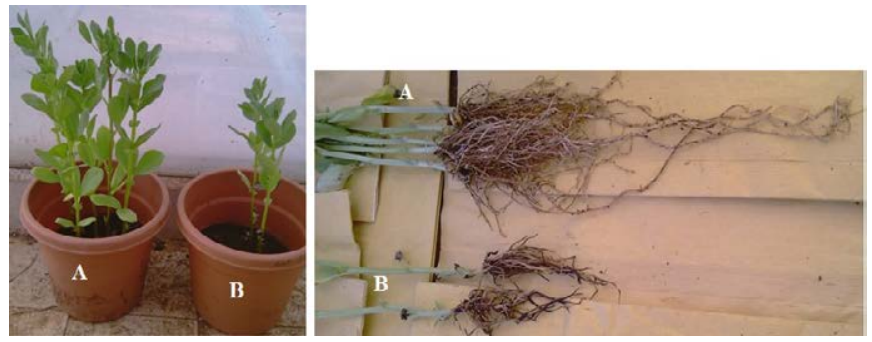

Figure 2: Greenhouse pot experiment illustrating the efficacy of Trichoderma isolates in the suppression of black root rot infection in four weeks old faba bean seedlings. Faba bean plants inoculated with bioagents $(A)$ showed better shoot and root biomass than plants treated with $F$. solani alone (B).

fresh biomass over control. The least reduction in plant fresh weight was observed in plants treated with TS047 (42.4 g). Better overall growth of seedlings indicated the efficiency of Trichoderma antagonists in controlling faba bean black root rot.

\section{Discussion}

Trichoderma is known antagonist of plant pathogens, and has been shown to be very efficient biological control agent of several soil-borne 
plant pathogenic fungi $[12,13,33]$. Trichoderma is a good candidate for biological control due to the different modes of action that inhibit the growth of other fungi. The study was undertaken to determine the potentials of locally isolated antagonistic Trichoderma spp. that perform as biological control agents for the management of $F$. solani, which is responsible for black root rot on faba bean.

The results revealed that the isolates of Trichoderma spp., which were obtained from the rhizosphere soil of healthy bean plants, had effective biological control activity against Fusarium solani under in vitro and in vivo pot experiments. The potentiality of Trichoderma spp. as biological control agents of phytopathogenic fungi in several crops is well known, especially to Fusarium solani infection [34]. T. harzianum, $T$. koningii and T. viride protected the germinating bean seedlings against Fusarium spp. and R. solani infection [19,35].

Antagonistic capability of all Trichoderma isolates showed inhibitory effect against mycelial growth of $F$. solani in dual in vitro testing. The percentage of mycelial growth inhibition by the Trichoderma isolates against F. solani varied between 33.9 and $67.0 \%$. Some isolates were highly inhibitory to $F$. solani growth, whereas others showed only lower activity. In the medium, the Trichoderma isolates grew much faster and suppressed the growth of $F$. solani in vitro. The competition mechanism of Trichoderma depends on their rapid growth rate limiting nutrients and space for $F$. solani and this may produce inhibition of F. solani growth up to $67 \%$. Effective biological control agents inhibit the growth of the target organisms through their ability to grow much faster than the pathogenic fungi thus competing efficiently for space and nutrients [13]. Starvation is the most common cause of death for microorganisms, so that competition for limiting nutrients results in biological control of fungal phytopathogens. Competition is effective when the pathogen conidia need exogenous nutrients for germination and germ-tube elongation [36].

A second mechanism of pathogen control that Trichoderma displayed was mycoparasitism. The mycoparasitic activity of the tested Trichoderma isolates was detected morphologically by subsequent profuse sporulation of Trichoderma and its ability to overgrow upon the mycelial growth of $F$. solani in culture which may indicate its ability to directly parasitize the pathogen. Trichoderma species exert biological control against fungal phytopathogens either indirectly by competing for nutrients and space, modifying the environmental conditions, or promoting plant growth and plant defensive mechanisms and antibiosis, or directly by mechanisms such as mycoparasitism [15,16,37].

The Trichoderma isolates, which showed high efficacy in vitro study, also significantly reduced the root rot severity in the greenhouse. The effective colonization of faba bean roots by Trichoderma isolates might have contributed to their capability to inhibit $F$. solani infection on faba bean roots. The effect of antagonist on the faba bean plant growth under pot condition revealed that faba bean seedlings grown in Trichoderma-treated soils had taller plant height and fresh weight than F. solani alone inoculated faba bean plants. The isolates significantly reduced black root rot severity on faba bean seedlings with disease reduction ranging from 64.4 to $74.6 \%$ over control. Application of the antagonist Trichoderma spp. as seed treatment significantly reduced the incidence of Fusarium spp. and R. solani in some leguminous crops $[19,35]$, and grew readily along with the developing root system of the treated plants $[35,37,38]$. This might due to modification of the rooting system.

\section{Conclusion}

All antagonist species of Trichoderma isolates proved to be effective in controlling Fusarium solani, both under laboratory and pot conditions. The results indicate that the selected Trichoderma species could be potential sources of antagonistic agents for the management of black root rot on faba bean grown in the highlands of northeastern Ethiopia, where biological control agents can be used as one of the components in the integrated management of the disease. However, applying biological control agents in the field is influenced by many environmental, biological and physical factors. So, it desirable to evaluate further the biological control potential of the Trichoderma spp. under field conditions.

\section{Acknowledgments}

This research was financed by Ministry of Education (MOE), Ethiopia. The authors thank all Plant Pathology Laboratory technicians, Haramaya University, for their assistance in data collection and laboratory works.

\section{References}

1. Tilaye A, Getachew T, Demtsu B (1994) Genetics and breeding of faba bean In: Tilaye, Asfaw (eds.), Cool Season Food Legumes in Ethiopia. Addis Ababa, Ethiopia, pp. 97-121

2. Gorfu D, Beshir T (1994) Faba bean disease in Ethiopia. In: Asfaw Tilaye (ed) Cool Season Food Legumes in Ethiopia. Addis Ababa, Ethiopia, pp 328-345.

3. Bekele B, Muhammed G, Gelano T, Belayneh T (2003) Faba Bean and Fieldpea Diseases Research. In: Ali K (ed) Food and Forage Legumes: Progress and Prospects. Progress of the Workshop on Food and Forage Legumes. Addis Ababa, Ethiopia, pp. 221-227.

4. PPRC (Plant Protection Research Center) (1996) Progress Report for the period of 1995/96. PPRC. Ambo, Ethiopia. p. 53

5. Beshir T (1996) Evaluation of faba bean cultivars for resistance to black roo rot (Fusarium solani). In: Nile Vally and Red Sea Regional Program on CoolSeason Food Legumes and Cereals. Cairo, Egypt, pp. 72-76.

6. SARC (Sirinka Agricultural Research Center) (2005) Crop Protection Research Progress Report. SARC. Sirinka, Woldia.

7. Barakat R, Al-Masri MI (2005) Biological control of gray mold disease (Botrytis cinerea) on tomato and bean plants by using local isolates of Trichoderma harzianum. Dirasat, Agricultural Sciences 32: 145-156.

8. Pal KK, Gardener BM (2006) Biological Control of Plant Pathogens. The Plant Health Instructor pp. 1-25.

9. Vinale F, Sivasithamparam K, Ghisalberti EL, Marra R, Lorito SL (2008) Trichoderma - plant pathogens interactions. Soil Biology \& Biochemistry 40 1-10.

10. Abdel-Kadir MM, El-Mougy NS, Ashour AMA (2002) Suppression of root rot incidence in faba bean fields by using certain isolates of Trichoderma. Egypt Journal of Phytopathology 30: 15-25.

11. Janisiewicz WJ, Tworkoski TJ, Sharer C (2000) Characterizing the mechanism of biological control of postharvest diseases on fruits with a simple method to study competition for nutrients. Phytopathology 90: 1196-1200.

12. Whipps JM, Lumsden RD (2001) Commercial use of fungi as plant disease biological control agents: status and prospects. In: Butt TM, Jackson C, Magan $\mathrm{N}$ (eds) Fungi as Biocontrol Agents: Progress, Problems and Potential, CAB Publishing: Wallingford, UK, p. 390

13. Harman GE, Howell CR, Viterbo A, Chet I, Lorito M (2004) Trichoderma species--opportunistic, avirulent plant symbionts. Nat Rev Microbiol 2: 43-56.

14. Harman GE (2000) Myths and dogmas of biocontrol: changes in perceptions derived from research on Trichoderma harzianum T- 22. Plant Disease 84 377-393.

15. Howell CR (2003) Mechanisms employed by Trichoderma species in the biological control of plant diseases: The History and Evolution of Current Concepts. Plant Disease 87: 1-10.

16. Benítez T, Rincón AM, Limón MC, Codón AC (2004) Biocontrol mechanisms of Trichoderma strains. Int Microbiol 7: 249-260.

17. Mohidden FA, Khan MR, Khan SM, Bhat BH (2012) Why Trichoderma is considered superhero (super-fungus) against the evil parasite? Plant Pathology Journal 9: 92-102. 
Citation: Belete E, Ayalew A, Ahmed S (2015) Evaluation of Local Isolates of Trichoderma Spp. against Black Root Rot (Fusarium solani) on Faba Bean. J Plant Pathol Microb 6: 279. doi:10.4172/2157-7471.1000279

18. Lewis JA, Larkin RP, Rogers DL (1998) A formulation of Trichoderma and Gliocladium to reduce damping-off caused by Rhizoctonia solani and saprophytic growth of the pathogen in soilless mix. Plant Diseases 82: 501-506.

19. Abou-Zeid NM, Arafa MK, Attia S (2003) Biological control of pre- and postemergence diseases on faba bean, lentil and chickpea in Egypt. Egypt Journal of Agriculture Research 81: 1491-1503.

20. Pieta D, Pastucha A, Patkowska E (2003) The use of antagonistic microorganisms in biological control of bean diseases. Sodininlysteir Darzininkyste 22: 401-406.

21. Pieta D, Pastucha A (2004) Biological methods of protecting common bean (Phaseolus ulgaris, L.) Folia Universitaris Agriculturae Stetinensis Agricultura 95: 301-305.

22. Abdel-Kader MM (1997) Field application of Trichoderma harzianum as biocide for control of bean root rot. Egypt Journal of Phytopathology 25: 19-25.

23. Belayneh T (2003) Evaluation of native Trichoderma isolates of Ethiopia for biological control of Fusarium solani of faba bean. MSc. Thesis Presented to the School of Graduate Studies, Haramaya University. p. 70.

24. Beshir T (1999) Evaluation of the potential of Trichoderma viride as biological control agent of root rot disease, Fusarium solani, of faba bean. Pest Management Journal of Ethiopia 3: 91-94

25. Waksman SA (1922) A Method for Counting the Number of Fungi in the Soil. Bacteriol 7: 339-341.

26. Kubicek CP, Harman GE (2002) Trichoderma and Gliocladium: Basic Biology, Taxonomy and Genetics. I: 278.

27. Coskuntuna A, Ãzer N (2008) Biological control of onion basal rot using Trichoderma harzianum and induction of antifungal compounds in onion se following seed treatment. Crop Protection 27: 330-336.

28. Abeysinghe S (2007) Biological control of Fusarium solani f.sp. phaseoli the causal agent of root rot of bean, using Bacillus subtilis CA32 and Trichoderma harzianum RU01. Ruhuna Journal of Science 2: 82-88.

29. McFadden W, Hall R, Phillips LG (1989) Relations of initial inoculum density to severity of fusarium root rot of white bean in commercial fields. Canadian Journal of Plant Pathology 11: 122-126.

30. Villajuan-Abgona R, Kagayama K, Hyakumachi M (1996) Biocontrol of Rhizoctonia damping-off of cucumber by non-pathogenic binucleate Rhizoctonia. Europian Journal of Plant Pathology 102: 227-235.

31. SAS Institute (2004) SAS/STATA User Guide for Personal Computers Version 9.1 edition. SAS Institute. Carry, NC, USA.

32. Gomez KA, Gomez AA (1984) Statistical procedures for agricultural research, 2ndEd. John Wiley and Sons, New York.

33. Rosa DR, Herrera CJL (2009) Evaluation of Trichoderma spp. as biocontro agents against avocado white root rot. Biological Control 51: 66-71.

34. Rojo FG, Reynoso MM, Sofia MF, Chulze N, Torres AM (2007) Biological control by Trichoderma species of Fusarium solani causing peanut brown root rot under field conditions. Crop Protection 26: 549-555.

35. Raats PAC (2012) Effect of Trichoderma species on damping-off disease incidence, some plant enzymes activity and nutritional status of bean plants. International Journal of Agriculture and Environment 2: 13-25.

36. Elad Y (2000) Biological Control of Foliar Pathogens by Means of Trichoderma harzianum and Potential Modes of Action. Crop Protection 19: 709-714.

37. Harman GE (2006) Overview of Mechanisms and Uses of Trichoderma spp. Phytopathology 96: 190-194.

38. Howell CR, Hanson LE, Stipanovic RD, Puckhaber LS (2000) Induction of Terpenoid Synthesis in Cotton Roots and Control of Rhizoctonia solani by Seed Treatment with Trichoderma virens. Phytopathology 90: 248-252. 